\title{
Estado del arte de los materiales a base de cemento que contienen $\mathrm{TiO}_{2}$ : propiedades auto-limpiantes
}

\section{State of the art of $\mathrm{TiO}_{2}$ containing cementitious materials: self-cleaning properties}

\author{
A. Maury ${ }^{(*)}, \underline{\text { N. De Belie }}{ }^{(*)}$
}

Recepción/Received: 3-VII-08

Aceptación/Accepted: 26-I-09

Publicado online/Online publishing: 24-V-10

\section{RESUMEN}

Debido a las características físico-químicas de los materiales a base de cemento, la calidad estética de estos materiales tiende a disminuir con facilidad. Por otra parte, la actividad fotocatalítica producida por los materiales a base de cemento que contienen $\mathrm{TiO}_{2}$, ha permitido incorporar recientemente en estos materiales propiedades de auto-limpieza y purificación del aire. Sin embargo, actualmente sólo existe en el mercado un número limitado de dichos materiales, dado que aún se necesita conocer mejor las mencionadas propiedades. Para mejorar esta situación, se vienen desarrollando ensayos no estandarizados donde se evalúa la foto-degradación de colorantes orgánicos producida por los diferentes materiales. Por tanto, se han producido una gran cantidad de resultados no fácilmente comparables entre sí. Este artículo presenta una descripción de los diferentes ensayos de laboratorio desarrollados, así como una evaluación del potencial de auto-limpieza de los primeros edificios que contienen $\mathrm{TiO}_{2}$. Finalmente, se identifican los futuros desafíos de investigación en este campo.

Palabras clave: dióxido de titanio, fotocatálisis, autolimpieza, materiales a base de cemento, colorantes orgánicos.

\section{SUMMARY}

Due to the physico-chemical characteristics of cementitious materials the aesthetic quality of these materials tend to decrease easily. On the other hand, the photocatalytic activity produced by $\mathrm{TiO}_{2}$ loaded cementitious materials have recently allowed them to include self-cleaning and air-purifying properties. However, because a better understanding of these properties is still needed, only a limited number of these materials is present in the construction market. As a strategy to improve this situation, non standards tests based on photodegradation of organic dyes have become widely used to evaluate the photocatalytic action of the different materials. Today, a wide spectrum of non easily comparable results have been produced. In order to improve this situation, this paper focuses on the description of the developed laboratory tests as well as on the evaluation of the self-cleaning potential of the first buildings containing $\mathrm{TiO}_{2}$. Finally, future research challenges in this field are identified.

Keywords: titanium dioxide, photocatalysis, self-cleaning, cementitious materials, organic dyes.

(*) Ghent University, Gante, Bélgica. 


\section{INTRODUCCIÓN}

Los materiales a base de cemento, especialmente aquellos expuestos a la intemperie, presentan un proceso de deterioro acelerado debido a la exposición continua y directa a muchos contaminantes atmosféricos (orgánicos, inorgánicos y material en partículas) y a diferentes tipos de micro-organismos (tales como algas, hongos y cyanobacterias). A lo anterior, se le suman los cambios frecuentes en las condiciones ambientales a los que están sometidos. Esta situación puede producir, en muchos casos, importantes cambios en las propiedades de los materiales, especialmente en las propiedades estéticas. Por ejemplo, el color de un material de la fachada de una edificación debe tener una apariencia agradable y proyectar al público una percepción adecuada de la calidad y del mantenimiento de la edificación. Sin embargo, se producen importantes cambios de color en edificaciones o estructuras debido a las características físico-químicas de los materiales a base de cemento tales como rugosidad, porosidad y composición mineralógica, las cuales permiten con facilidad la deposición de contaminantes orgánicos colorantes, material en partículas, y facilitan también, en cierto grado, el crecimiento microbiológico.

El uso de aditivos, sellantes, solventes químicos, pinturas, trabajos de reparación y restauración son las prácticas comunmente utilizadas para evitar y controlar los cambios de color en los materiales a base de cemento. Sin embargo estos esfuerzos, aunque significativos, no han sido suficientes para eliminar el problema completamente. Lo anterior se debe a que el efecto de los contaminantes atmosféricos y los micro-organismos en estos materiales no son fenómenos del todo conocidos (1-2). Por otro lado, aparte de los costos directos de estas actividades, los costos indirectos ambientales y operacionales también deberían ser considerados en la selección de las soluciones. Por tanto, resulta necesario ofrecer nuevos materiales a base de cemento que sean eficientes, innovadores y más respetuosos con el medio ambiente.

El aprovechamiento de las propiedades fotocatalíticas del $\mathrm{TiO}_{2}$ (dióxido de titanio) en los materiales a base de cemento ha permitido la degradación de un determinado rango de compuestos orgánicos (COVs) e inorgáni$\cos \left(\mathrm{NO}_{x}\right.$ y $\left.\mathrm{SO}_{2}\right)$ los cuales son al mismo tiempo agresivos tanto para las propiedades del material como para el medio ambiente. Por este motivo, el dióxido de titanio podría ser utilizado para incrementar la vida útil de los materiales a base de cemento al tiempo que podría utilizarse para disminuir substancialmente la concentración de algunos contaminantes del aire; especialmente, en lugares semi-cerrados como son importantes avenidas urbanas, túneles o lugares muy contaminados como estaciones de gasolina o algunas industrias específicas.

\section{INTRODUCTION}

Because cementitious materials, especially those exposed to outdoor conditions, are direct and continuously exposed to many atmospheric pollutants, (organic, inorganic and particulate matter), microorganisms (e.g. algae, fungi, cyanobacteria) and different weather conditions, they have an accelerated deterioration process which can produce in many cases important changes in the materials' properties, specially on aesthetic properties. The colour from a material belonging to a building facade, for example, has to offer a pleasant appearance that should project to the public an adequate perception of the quality and maintenance of the building. However, serious colour changes are produced on buildings and structures due to the mineral composite nature of cementitious materials which causes relatively high porosity, roughness and a rich mineral composition that enable the easy deposition of coloured organic pollutants, particulate matter and partially facilitates microbiological growth.

In order to avoid and control colour changes of cementitious materials, common practices such as the use of additives, sealers, chemical cleaners, paintings, restoration and repairing works are widely used in buildings or structures. Nevertheless, this effort, though valuable, has not led to a complete elimination of the problem because the effect of atmospheric pollutants and micro-organisms on cementitious materials is not entirely known (1-2). On the other hand, apart from the direct costs of these activities, indirect costs related with environmental and operational losses should be also considered in the solutions selection process. It is therefore important to tackle these problems by formulating efficient, innovative and more environmentally friendly cementitious materials.

Application of $\mathrm{TiO}_{2}$ photocatalysis on cementitious materials has enabled the degradation of a range of organic (e.g. VOCs) and inorganic compounds (e.g. NO and $\mathrm{SO}_{2}$ ) which are at the same time aggressive towards materials' properties and the environment. Thus, $\mathrm{TiO}_{2}$ (titanium dioxide) could be used to increase the life cycle of cement based materials while it could also substantially decrease the concentration of some air pollutants, especially in confined spaces such as canyon streets, tunnels and parking lots or very polluted spaces such as gas stations or some specific industries. 
Sin embargo, dado que se requiere un mayor conocimiento del fenómeno fotocatalítico del $\mathrm{TiO}_{2}$ en los materiales a base de cemento, solamente un número limitado de productos que utilizan esta tecnología está disponible en el mercado de la construcción. Por lo tanto, ensayos basados en la fotodegradación de colorantes orgánicos están siendo ampliamente utilizados para evaluar el potencial fotocatalítico de diferentes materiales a base de cemento que contienen $\mathrm{TiO}_{2}$. No obstante, la inexistencia de estándares para estos ensayos ha permitido la generación de resultados no-comparables. Con el ánimo de mejorar esta situación, este artículo describe los ensayos de laboratorio realizados en materiales a base de cemento que contienen $\mathrm{TiO}_{2}$ con el objeto de crear edificaciones auto-limpiantes; especialmente, basados en ensayos de degradación fotocatalítica de colorantes orgánicos. De igual manera, se describen algunos parámetros para controlar los cambios de color durante los ensayos; adicionalmente, basados en los resultados colorimétricos obtenidos en las primeras edificaciones que contienen $\mathrm{TiO}_{2}$, se ha evaluado el potencial de crear edificios auto-limpiantes. También, se describe la actividad alguicida del $\mathrm{TiO}_{2}$ en un tipo de hormigón. Finalmente, se identifican los futuros desafíos de investigación sobre los materiales a base de cemento con propiedades auto-limpiantes derivadas del uso del $\mathrm{TiO}_{2}$.

\section{FOTOCATÁLISIS DEL DIÓXIDO DE TITANIO}

Cuando el dióxido de titanio es expuesto a luz que contiene rayos UV, propiedades de purificación del aire, propiedades auto-limpiantes y propiedades antimicrobianas se pueden generar espontánea y simultáneamente en la superficie del material que lo contiene. Esto es debido a que el dióxido de titanio es un material fotocatalítico que tiene una estructura electrónica compuesta por dos bandas, la banda de valencia (llena de electrones) y la banda de conducción (sin electrones). La diferencia energética entre la banda de conducción y la banda de valencia es la llamada banda prohibida, y cuando un fotón con una energía superior a ésta, entra en contacto directo con este material fotocatalítico, un electrón ( $e^{-}$) de la banda de valencia se mueve hacia la banda de conducción, dejando así un hueco electrónico $\left(\mathrm{h}^{+}\right)$. Una porción del par foto-excitado hueco-electrón se difunde hacia la superficie del material fotocatalítico, lugar donde es retenido para participar en reacciones químicas con moléculas de oxígeno y agua presentes en el medio ambiente. Los huecos electrónicos $\left(\mathrm{h}^{+}\right)$pueden reaccionar con moléculas donantes adsorbidas como las de agua para producir los radicales hidroxilos (altamente reactivos). Actuando como receptor de electrones, el oxígeno presente en el aire puede reaccionar con los electrones para formar los aniones radicales superoxidantes $\left(\mathrm{O}_{2}^{-}\right)$. Los radicales hidróxilos (oxidantes) y los aniones radicales
However, because a better understanding of titanium dioxide photocatalysis phenomena on cement based materials is still needed, only a limited number of products using this technology is present in the construction market. As a strategy to improve this situation, tests based on photodegradation of organic dyes have become widely used to evaluate the photocatalytic potential of different $\mathrm{TiO}_{2}$ loaded cementitious materials. In spite of this, the inexistence of standards for these tests on cement based materials has produced non-comparable results. In order to improve this situation, this paper describes the developed laboratory tests on cementitious materials containing $\mathrm{TiO}_{2}$ for self-cleaning purposes, specially based on executed tests for photodegradation of organic dyes. Some parameters to control color changes during the tests are described. Furthermore, based on colorimetric results obtained from pioneering buildings containing $\mathrm{TiO}_{2}$, the potential for developing self-cleaning buildings is evaluated. Also, algicidal activity of $\mathrm{TiO}_{2}$ photocatalysis on cementitious materials is described. Finally, future research challenges about self-cleaning cementitious materials using $\mathrm{TiO}_{2}$ are identified.

\section{TITANIUM DIOXIDE PHOTOCATALYSIS}

When exposing titanium dioxide to light containing UV rays, air-purifying, self-cleaning and antimicrobial mechanisms can be spontaneous and simultaneously generated on material surfaces containing $\mathrm{TiO}_{2}$. Titanium dioxide is a photocatalyst material which has an electronic structure formed by two bands, the valence band (with electrons) and the conduction band (without electrons). If a photon with an energy exceeding the band gap, the difference between the valence and conduction band, is in direct contact with this photocatalyst, then an electron $\left(e^{-}\right)$is promoted from the valence band to the conduction band leaving an electronic hole $\left(h^{+}\right)$behind. A portion of this photo-excited electron-hole pair diffuses to the surface of the photocatalytic material (electron-hole pairs are trapped at the surface) and takes part in chemical reactions with water and oxygen molecules present in the environment. The holes $\left(h^{+}\right)$can react with adsorbed donor molecules such as water to produce the highly reactive hydroxyl radical $\left(\mathrm{OH}^{-}\right)$. Acting as electron acceptor, air oxygen can react with the electrons $\left(e^{-}\right)$to form the superoxide radicalanion $\left(\mathrm{O}_{2}^{-}\right)$. Hydroxyl radicals (oxidants) and superoxides radical-anions (reductants) generated on $\mathrm{TiO}_{2}$ have shown strong ability to degrade different micro-organisms (3-4), almost all kinds of organic 
superoxidantes (reductores) generados sobre la superficie del $\mathrm{TiO}_{2}$ han demostrado una gran capacidad para degradar diferentes tipos de microrganismos (3-4), casi todos los tipos de contaminantes orgánicos (5-6) y otros compuestos inorgánicos tales como $\mathrm{NO}_{\mathrm{x}}(7)$ y $\mathrm{SO}_{2}$ (5).

En general, la rapidez de degradación de los compuestos es función de la absorción de la luz, transporte de las cargas fotogeneradas $\left(\mathrm{e}^{-} \mathrm{y} \mathrm{h}^{+}\right)$a la superficie, recombinación de $\mathrm{e}^{-} \mathrm{y} \mathrm{h}^{+}$, reacción de $\mathrm{e}^{-} \mathrm{y} \mathrm{h}^{+}$, sobre la superficie del fotocatalizador, transferencia de masa de los reaccionantes y las características de las partículas, en relación tanto con las características estructurales como con las morfológicas (8-9). El dióxido de titanio puede cristalizar en tres tipos de estructuras cristalinas que son: rutilo (tetragonal), anastase (tetragonal) y brookita (ortorrómbica). De estas tres formas cristalinas del $\mathrm{TiO}_{2}$, el rutilo es la más estable, ya que la anastase y la brookita se transforman en rutilo bajo calentamiento. A pesar de la anterior similitud entre anastase y brookita, esta última se encuentra escasamente en relación con la forma anastase, y además no presenta significativa actividad fotocatalítica cuando es usada con luz visible. Por lo tanto, los tipos rutilo y anastase tienen más aplicaciones industriales. El rutilo, por su parte, tiene la banda prohibida más pequeña, 3,0 eV (equivalente a $413 \mathrm{~nm}$ en longitud de onda), mientras que el anastase tiene la banda prohibida más amplia, 3,2 eV (388 nm). Ambas bandas prohibidas están cercanas a la longitud de onda límite entre la longitud de onda larga de luz UV (315-400) y la luz visible (400-700). Cuando se han utilizado longitudes de onda larga de UV provenientes solamente de luz visible se ha observado una importante disminución de la actividad fotocatalítica del $\mathrm{TiO}_{2}$. Por lo tanto, se han realizado muchos esfuerzos para reducir la magnitud de la banda prohibida y permitir que el efecto fotocatalítico del $\mathrm{TiO}_{2}$ se pueda obtener con luz visible. Se destacan entre estas estrategias, la utilización del doping de metales (hierro y tungsteno) y no metales (carbono, nitrógeno y sulfuro) en el $\mathrm{TiO}_{2}$ (10).

Desde los comienzos del siglo $\mathrm{XX}$, el dióxido de titanio tipo rutilo ha sido utilizado como pigmento para las pinturas, cosméticos y otros. Sin embargo, su elevada capacidad para degradar compuestos orgánicos destruía los adhesivos orgánicos, produciendo así el fenómeno de las pinturas conocido como efecto tiza "Chalk effect". Actualmente, para evitar este efecto, los pigmentos de $\mathrm{TiO}_{2}$ se recubren con diferentes óxidos tales como alúmina, sílice y zirconio, los cuales disminuyen la cantidad de radicales y óxidos producidos. Sólo hasta 1969, el trabajo de investigación de Fujishima y Honda sobre la separación fotocatalítica del agua usando electrodos de dióxido de titanio (tipo anastase) hizo posible la utilización de las propiedades fotocatalíticas con otros fines (11). pollutants (5-6) and other inorganic compounds such as $\mathrm{NOx}$ (7) and $\mathrm{SO}_{2}$ (5).

In general, the degradation rate of compounds is governed by light absorption, transport of photogenerated charges $\left(e^{-}\right.$and $\left.h^{+}\right)$to the photocatalyst surface, recombination of $e^{-}$and $h^{+}$, reaction of $e^{-}$and $h^{+}$on the photocatalyst surface, mass transfer of reactants to the surface and the features of the particles, with respect to both structural and morphological characteristics (8-9). Titanium dioxide can crystallize in three crystalline structures types, rutile (tetragonal), anatase (tetragonal) and brookite (orthorhombic). Among these crystalline forms, rutile is thermodynamically the most stable, because anatase and brookite transform to rutile on heating. In spite of this similarity between anatase and brookite, the last one occurs rarely compared to the anatase form of $\mathrm{TiO}_{2}$ and exhibits no significant photocatalytic activity with visible light. Then, rutile and anatase forms have more industrial applications. Rutile has the smallest band gap, $3.0 \mathrm{eV}$ (equal to $413 \mathrm{~nm}$ cut-off wave length), while anatase has the biggest band gap, 3.2eV (388 nm). Both band gaps are close to the limiting wavelength between long wave length UV light (315-400 $\mathrm{nm})$ and visible light (400-700 nm). When using only long wave length UV light contained in visible light an important decrease of the photocatalytic activity has been noticed. Consequently, many efforts have been done in doping $\mathrm{TiO}_{2}$ with metals like iron and tungsten or non metals like carbon, nitrogen and sulphur in order to reduce the band gap energy to make the photocatalytic effect usable with visible light (10).

Since the early stage of the 20th century, titanium dioxide rutile type has been used as a pigment for paintings, cosmetics and others. However, the high ability of $\mathrm{TiO}_{2}$ to degrade organic compounds destroyed the organic binders, producing the painting phenomena known as "chalk effect". Today, for avoiding this effect, $\mathrm{TiO}_{2}$ pigments are very often coated with different oxides, like alumina, silica and zirconia which reduce the amount of produced radicals and oxides. Only since 1969, the research work of Fujishima and Honda on the photocatalytic splitting of water using titanium dioxide electrodes (anatase type) made it possible to use the photocatalytic properties with other goals (11). 
Inicialmente, las propiedades antibacteriales del $\mathrm{TiO}_{2}$ fueron utilizadas en sistemas de purificación de aire y agua (12-14). Posteriormente, fueron desarrolladas baldosas cerámicas con recubrimientos de dióxido de titanio con el fin de crear propiedades antisépticas en hospitales, escuelas, cocinas y duchas (15). Actualmente, la adición de metales tales como $\mathrm{Cu}$ and $\mathrm{Ag}$ al $\mathrm{TiO}_{2}$ ha incrementado sus propiedades antibacteriales (10).

En 1995, se descubrió accidentalmente que los recubrimientos de $\mathrm{TiO}_{2}$ que contenían un cierto porcentaje de sílice $\left(\mathrm{SiO}_{2}\right)$ desarrollaban un comportamiento hidrofílico cuando se encontraban en contacto con el agua y expuestos a luz UV (16-17). Lo anterior se debe a que las moléculas de agua parecen tender a formar enlaces de hidrógeno con los grupos $\mathrm{OH}^{-}$, los cuales son generados durante la exposición del $\mathrm{TiO}_{2}$ a la luz UV. Por lo tanto, el agua (por ejemplo aquella proveniente de precipitaciones) tiende a formar capas en vez de acumularse como gotas sobre estos materiales. En general, cuando no hay exposición del material a luz UV y además el $\mathrm{TiO}_{2}$ es utilizado sin sílice, el comportamiento hidrofílico se detiene mientras que cuando el $\mathrm{TiO}_{2}$ es combinado con sílice, o incluso con algún compuesto de sílice que posee enlaces de siloxano, el efecto hidrofílico se mantiene por un largo periodo, incluso en la oscuridad (18). Actualmente, el comportamiento hidrofílico del $\mathrm{TiO}_{2}$ ha sido extensivamente aplicado en vidrios y espejos para mantener las propiedades ópticas de estos materiales bajo condiciones atmosféricas que son adecuadas para la condensación del vapor de agua. De igual modo, recientemente se ha anunciado una nueva manera de obtener propiedades de auto-limpieza en las superficies que contienen $\mathrm{TiO}_{2}$, la cual consiste en la introducción de un comportamiento dual (hidrofílico e hidrofóbico) creando rugosidad en las partículas de $\mathrm{TiO}_{2}$ por medio de una técnica foto-electroquímica de impresión (19). Sin duda alguna, este descubrimiento ampliará el campo de aplicación del $\mathrm{TiO}_{2}$ con fines de auto-limpieza.

A pesar de esto, los comportamientos hidrofílicos e hidrofóbicos producidos por la fotocatálisis del $\mathrm{TiO}_{2}$ son más pronunciados sobre superficies lisas como el vidrio y las cerámicas que en el caso de la superficie de los materiales a base de cemento. En estos últimos, este efecto es limitado debido a la elevada rugosidad, porosidad y permeabilidad. Sin embargo, mediante la acción fotocatalítica del $\mathrm{TiO}_{2}$ se puede obtener la degradación de sustancias orgánicas que manchan la superficie de los materiales a base de cemento $y$, en el caso de material particulado (inorgánico), la limpieza puede estar basada en la degradación de la capa orgánica que normalmente estos materiales utilizan como adherente; posteriormente, una completa remoción de las partículas remanentes puede hacerse con agua (por ejemplo, aquélla proveniente de precipitaciones).
Initially, the antibacterial properties of titanium dioxide were used in air and water purification systems (12-14). Then, ceramic tiles with titanium dioxide coatings were developed for creating antiseptic properties in hospitals, schools, kitchens and baths (15). Today, addition of metals such as $\mathrm{Cu}$ and $\mathrm{Ag}$ to $\mathrm{TiO}_{2}$ has increased its antibacterial properties (10).

In 1995, it was found by accident that $\mathrm{TiO}_{2}$ films containing a certain percentage of silica $\left(\mathrm{SiO}_{2}\right)$ developed a hydrophilic behaviour when they were in contact with water and exposed to UV light (16-17). This because water molecules seems to be prone to form hydrogen bounds with $\mathrm{OH}^{-}$groups which are generated during exposure of $\mathrm{TiO}_{2}$ to UV light. So, water (e.g. rainwater) tends to form films instead of depositing as droplets on these materials. In general, when there is no exposure of the material to UV light and also $\mathrm{TiO}_{2}$ is used without silica the hydrophilic behaviour is stopped, while when $\mathrm{TiO}_{2}$ is combined with silica or a chemical compound of silicon that has siloxane bonding, the hydrophilic effect of the surface continues for long time even in the dark (18). Nowadays, the hydrophilic behaviour of $\mathrm{TiO}_{2}$ has been extensively applied commercially in glasses and mirrors for keeping the optical properties of these materials under weather conditions that are favourable for the water vapour condensation. Also, recently, a new approach to obtain self-cleaning surfaces has been announced. Introducing roughness to $\mathrm{TiO}_{2}$ particles by a photoelectrochemical etching technique, a controlled hydrophilic and a hydrophobic behaviour in the same surface could be obtained (19). This discovery, it will certainly expand the application field of $\mathrm{TiO}_{2}$ for selfcleaning purposes.

In spite of this, the hydrophilic/hydrophobic behaviours produced by $\mathrm{TiO}_{2}$ photocatalysis are more pronounced on smooth surfaces like glass and ceramic tiles than in cementitious materials' surfaces. In the latter materials, this effect is limited due to their relatively high roughness, porosity and permeability. Nevertheless, due to $\mathrm{TiO}_{2}$ photocatalytic action, degradation of organic staining substances on cementitious materials could take place, and in the case of particle matter (inorganic), because this adheres to the surface of cementitious materials through an organic based interlayer, degrading this layer by $\mathrm{TiO}_{2}$ photocatalysis, a later cleaning process using water (e.g. with rain water) will remove easier the remaining particles. 


\section{AUTO-LIMPIEZA EN LOS MATERIALES A BASE DE CEMENTO}

Considerando los satisfactorios resultados obtenidos en las aplicaciones previas de la fotocatálisis del $\mathrm{TiO}_{2}$ $y$, por otro lado, las condiciones que ofrecen los edificios para su aplicación (exposición a la luz solar de áreas de importante tamaño), el dióxido de titanio ha sido aplicado en diferentes tipos de materiales a base de cemento. En este campo las aplicaciones han tenido como propósito obtener desde materiales auto-limpiantes hasta materiales con propiedades para la purificación del aire. Sin embargo, las primeras aplicaciones estuvieron centradas en obtener un proceso de limpieza autónomo (auto-limpieza) en las fachadas de los edificios, especialmente en los elementos elaborados con cemento blanco. Desde entonces, la evaluación de las propiedades de auto-limpieza en los materiales a base de cemento que contienen $\mathrm{TiO}_{2}$ se ha realizado mediante ensayos de laboratorio que utilizan colorantes orgánicos como modelo de los contaminantes. En la mayoría de los casos, se ha estimulado la actividad fotocatalítica usando diferentes tipos de lámparas que contienen rayos UV con amplia longitud de onda.

En 1996 se registraron los primeros experimentos de laboratorio sobre la actividad de auto-limpieza en materiales a base de cemento que contienen $\mathrm{TiO}_{2}$. Estos ensayos fueron desarrollados para el diseño de la mezcla del hormigón de la iglesia "Dives in Misericordia" (Roma, Italia), de los que resultó un nuevo tipo de cemento denominado TX Millennium. Usando una técnica aerográfica, muestras de cemento blanco (discos) que contenían 5\% de dióxido de titanio (Degussa P 25) fueron impregnados con fenantroquinona (colorante amarillo). Para activar al material fotocatalítico se empleó un simulador solar compuesto por 4 lámparas de $400 \mathrm{~W}(\lambda>290 \mathrm{~nm})$, mientras que para evaluar la foto-degradación del colorante se monitorizó la reflactancia (\%). Con base en esta última variable, se encontró que en sólo 8 horas se produjo una recuperación casi completa del color blanco de las muestras de cemento. Véase Figura 1 (20).

Otro ensayo de auto-limpieza fue desarrollado durante la ejecución del proyecto PICADA (Photocatalytic Innovative Coverings Applications for Depollution Assesment). En éste, dos materiales conteniendo $\mathrm{TiO}_{2}$ fueron impregnados con rodamina $\mathrm{B}$ (colorante rojo), un revocado (cemento blanco, cal y arena) y una pintura mineral (cemento blanco y llenantes). A 1 metro de distancia de las muestras, fue utilizada una lámpara UV (300 W) para activar el proceso de photo-degradación del colorante sobre las muestras que contenían $\mathrm{TiO}_{2}$ (Figura 2) (21).

\section{SELF-CLEANING ON CEMENTITIOUS MATERIALS}

Considering the successful results obtained in the previous applications of $\mathrm{TiO}_{2}$ photocatalysis and on the other hand, the conditions offered by building materials for its application (sun exposure of considerable surface areas), titanium dioxide has been applied in different cementitious materials. In this field, the applications have varied from self-cleaning to air-purifying purposes. However, the first applications were intended to obtain an automatic cleaning process on buildings facades (self-cleaning), especially for materials based on white cement. Since then, the self-cleaning activity of cementitious materials loaded with $\mathrm{TiO}_{2}$ has been evaluated through laboratory tests using organic dyes as pollutant models. In most of the cases, the photocatalytic activity has been stimulated by using different lamp types containing long wave length UV rays.

In 1996, the first laboratory experiments about the selfcleaning activity on cementitious materials containing $\mathrm{TiO}_{2}$ were reported. These tests were developed for designing the mix composition of the church "Dives in misericordia" (Rome, Italy). As a consequence a new cement type called TX Millennium resulted. Using an aerograph technique, white cement disks containing 5\% of titanium dioxide (Degussa P-25) were impregnated with phenantroquinone (yellow dye). A solar simulator composed by 4 lamps of $400 W(\lambda>290 \mathrm{~nm})$ was used to activate the $\mathrm{TiO}_{2}$ photocatalysis while the reflectance (\%) was used to follow the photodegradation of the dye. The last one showed that in only 8 hours almost a complete recovering of the colour of the white cement disks was obtained. See Figure 1 (20).

During the development of the PICADA project (Photocatalytic Innovative Coverings Applications for Depollution Assessment) a different self-cleaning test was developed. In this, two materials containing $\mathrm{TiO}_{2}$ were impregnated with rhodamine $B$ (red dye), a render (white cement, lime and sand) and a mineral paint (white cement and fillers). At one meter distance from the samples, a UV light (300 W) was used as mechanism to activate the photo-degradation process of the organic dye on the $\mathrm{TiO}_{2}$ loaded samples (Figure 2) (21). 


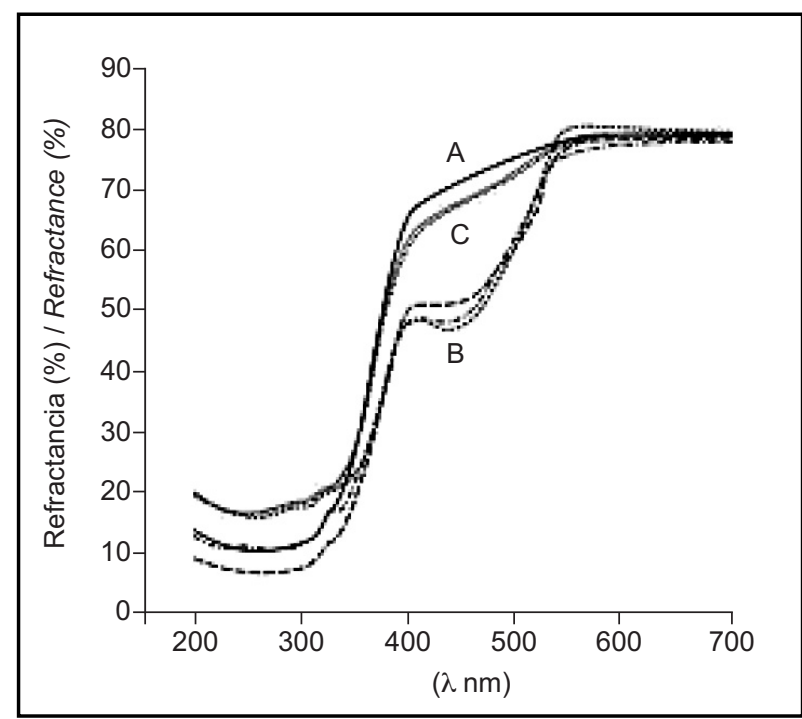

Figura 1. Evolución en el tiempo del espectro de la reflactancia de muestras de cemento blanco en las que se aplicó fenantroquinona (20). (A) Superficie original limpia, (B) superficie después de la deposición de fenantroquinona (línea discontinua),

(C) superficie después de $8 \mathrm{~h}$ de irradiación (línea punteada).

Figure 1. Time evolution of the reflectance spectra of $\mathrm{TiO}_{2}-$

loaded white cement samples in which phenanthroquinone was applied (20). (A) Original clean surface, (B) surface after deposition of phenanthroquinone (dashed line), (C) Surface after $8 \mathrm{~h}$ irradiation (dotted curves under curve $A$ ).

En este caso, la cantidad de dióxido de titanio incorporado en las mezclas no fue considerado; sin embargo, el tamaño de los cristales de $\mathrm{TiO}_{2}$ fue estimado en $20 \mathrm{~nm}$. Por otro lado, la foto-degradación del colorante fue monitorizada realizando mediciones de color, las cuales están basadas en el parámetro a* del sistema de color CIE L*a*b* (Commission Internationale de l'Eclairage). Este sistema descompone cualquier medición del color en tres factores. $\left(L^{*}\right)$ representa la luminosidad con valores entre blanco y negro, (a*) hace lo mismo con los valores entre rojo y verde, mientras que (b*) hace lo mismo con valores entre azul y amarillo. Teniendo en cuenta estos resultados, después de 24 horas de exposición a la luz UV, se obtuvo una recuperación de aproximadamente un $65 \%$ en ambos materiales (Figura 3) (21).

Dentro de este proyecto también se presentó un criterio útil para expresar y comparar las eficiencias de diferentes materiales que contienen $\mathrm{TiO}_{2}$. Este criterio denominado como $\mathrm{V}_{\mathrm{a}}$, velocidad de degradación del colorante, puede ser calculado en relación al factor a* para la rodamina B durante las tres primeras horas de exposición a la luz UV, tal como se expresa a continuación, ecs. [1] y [2]:

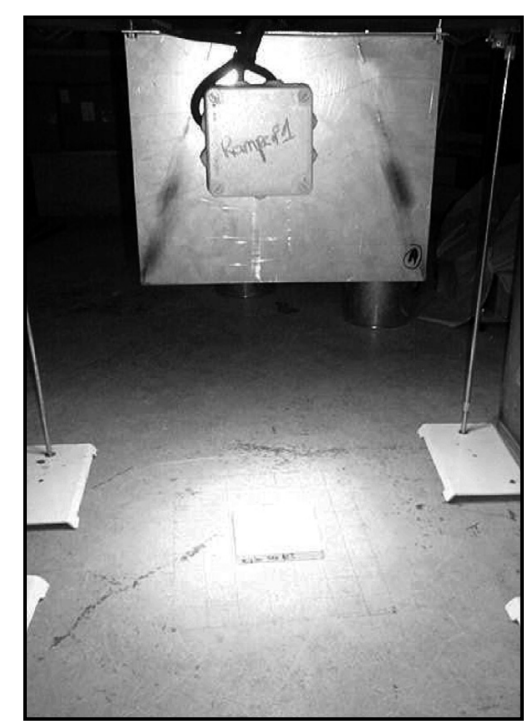

Figura 2. Proceso de foto-irradiación sobre las muestras de cemento que contienen $\mathrm{TiO}_{2}$ (21).

Figure 2. Photo-irradiation process on $\mathrm{TiO}_{2}$ loaded cementitious samples (21).
In this case, the amount of titanium dioxide was not reported. However, the titanium dioxide crystal size was estimated at $20 \mathrm{~nm}$. On the other hand, the photodegradation of the dye was followed by using colorimetric measurements based on the colorimetric parameter a* from colour system CIE L*a*b*(Commission Internationale de l'Eclairage). This system decomposes any colour measurements in three coordinates. $\left(L^{*}\right)$ plots the lightness with values between white and black, (a*) represents values between red and green, while $\left(b^{*}\right)$ does the same with values between blue and yellow. Based on these results, a recovering of the colour of around 65\% was obtained on both materials after the first 24 hours of UV light exposure (Figure 3) (21).

Also within this project, $V_{a *}$, a convenient criteria to express and compare self-cleaning efficiencies of different $\mathrm{TiO}_{2}$ loaded materials was presented. In the case of the degradation of the Rhodamine $B$, the dye degradation velocity could be calculated in relation to the a* factor during $0 h$ to $3 h$ as follows eqs. [1] and [2]:

$$
V_{a}^{*}=\left|\int_{0 h}^{t=3 h} \frac{\partial a^{*}}{\partial t} \partial t\right|
$$




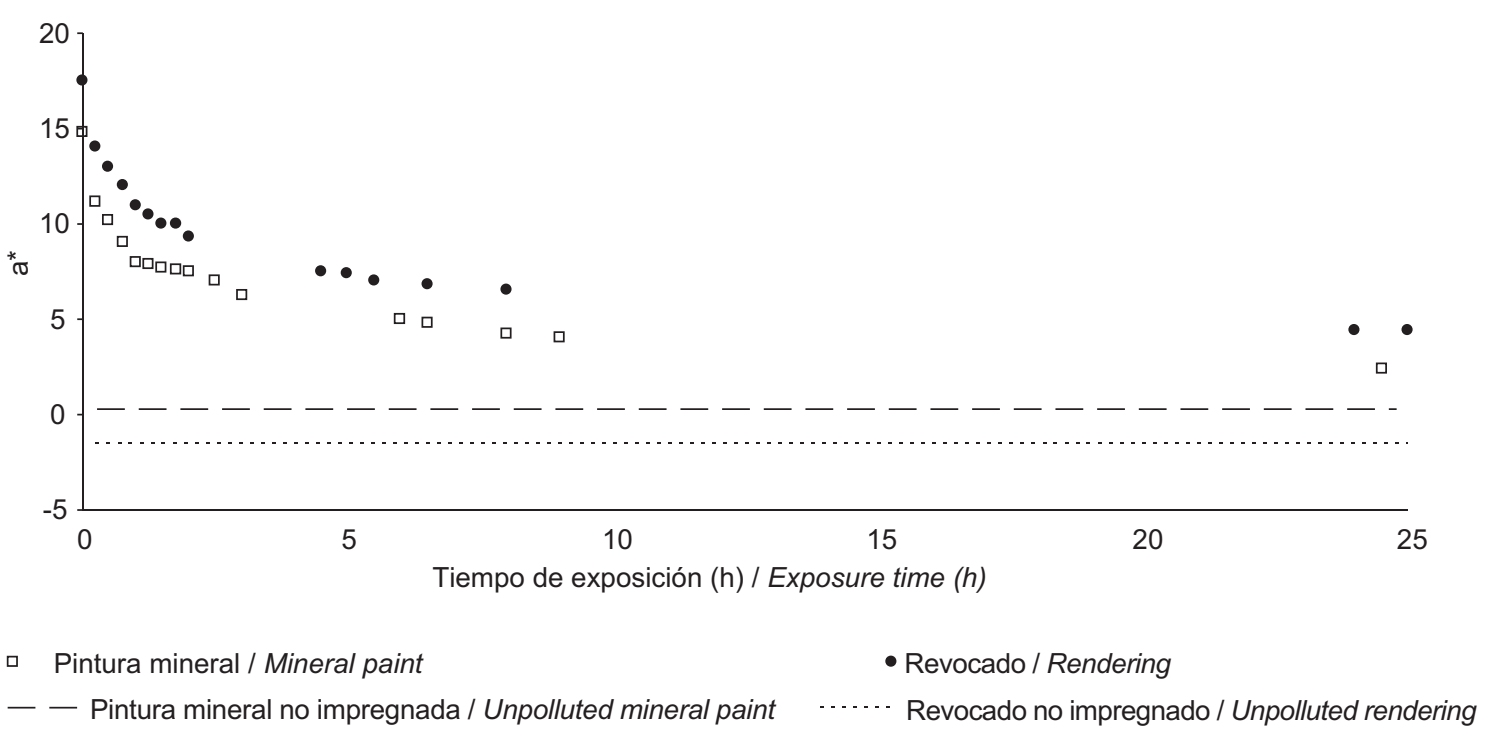

Figura 3. Evolución del cambio de color vs. tiempo en los materiales a base de cemento del proyecto PICADA (21). Figure 3. Evolution of color change vs. time on cement based materials from the PICADA project (21).

$$
a^{*}(t)=A \times e^{-B t}+\frac{C}{t+D}+a_{u n p}^{*}
$$

Donde $A, B, C$ y $D$ son parámetros determinados mediante la construcción de las curvas de regresión de los datos experimentales. $a^{*}$ unp corresponde al color de la muestra antes de la impregnación con rodamina $\mathrm{B}$.

Usando la ecuación anterior durante los ensayos de fotodegradación de la rodamina $B$, se encontró que la velocidad de degradación de este colorante muestra un comportamiento exponencial, el cual es típico de las reacciones de primer orden (21).

La actividad de auto-limpieza de los sistemas compuestos por $\mathrm{TiO}_{2}$ /cemento fue también evaluada en otros experimentos utilizando cubos de mortero blanco impregnados (utilizando brocha) con rodamina B. Si bien en este caso, se estudiaron diferentes proporciones de mezcla $\mathrm{TiO}_{2} /$ cemento, la información precisa sobre las diferentes composiciones de mezcla analizadas no está disponible. Por otro lado, usando una lámpara denominada "daylight lamp", la foto-degradación de la rodamina fue estimulada mientras que la rapidez de decoloración fue monitorizada justo después de la $4^{a}, 6^{a}$ y $24^{a}$ hora de exposición a la luz. Finalmente, entre 75 y $95 \%$ del color inicial fue recuperado después de esta última medición (Figura 4). Las anteriores diferencias son posiblemente debidas al uso de distintas cantidades y tipos de catalizadores en las mezclas (22).
Where $A, B, C$ and $D$ are parameters which are determined by fitting experimental curves. $a^{*}$ unp corresponds to sample colour before impregnation with rhodamine $B$.

Using the last expression the photo-degradation velocity of the rhodamine $B$ was calculated during the experiments. The velocity shows an exponential behaviour which is typical for first order reactions (21).

In other experiments, self-cleaning activity of $\mathrm{TiO}_{2}$ /cement systems was also evaluated by using white mortar cubes brush-impregnated with rhodamine $B$. In this case, different mix proportions of the $\mathrm{TiO}_{2}$ loaded materials were studied. However, no precise information about the mix compositions is available. Using a so called "daylight lamp", the photo-degradation of the rhodamine $B$ was stimulated. The decolouration rate after 4, 6 and 24 hours was measured. After 24 four hours of light exposure, the colour of the impregnated cubes was recovered between 75 and 95\% (Figure 4), these different efficiencies were possibly due to the use of different catalyst types and different catalyst amounts in the mixes (22). 


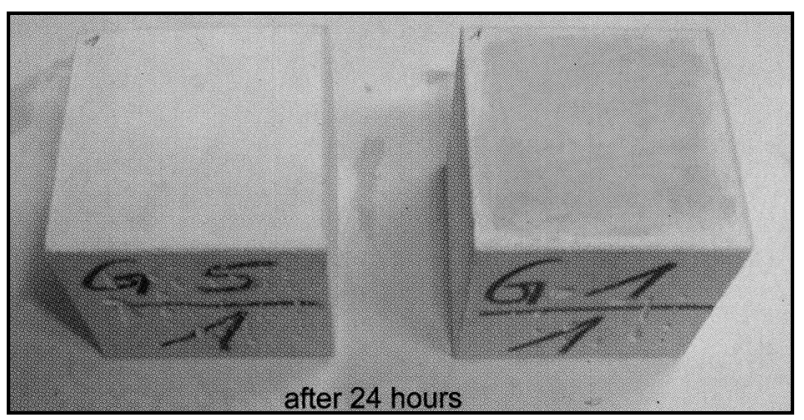

Figura 4. Ensayo del cubo de decoloración en cubos de mortero impregnados con rodamina B (22). Figure 4. Cube-discoloration test on mortar cubes impregnated with rhodamine B (22).

En otra investigación, con el propósito de monitorizar la fotodegradación de colorantes orgánicos sobre materiales a base de cemento que contienen $\mathrm{TiO}_{2}$ se propuso el cálculo de los factores $R_{4}$ y $R_{26}$, ecs. [3] y [4]:
In order to follow the photodegradation of organic dyes on cementitious materials, another research presented factors $R_{4}$ and $R_{26}$ which can be calculated as follows eqs. [3] and [4]:

$$
\begin{aligned}
& R_{4}=\frac{a^{*}(0 h)-a^{*}(4 h)}{a^{*}(0 h)} \times 100 \\
& R_{26}=\frac{a^{*}(0 h)-a^{*}(26 h)}{a^{*}(0 h)} \times 100
\end{aligned}
$$

Además, el cementante hidráulico es considerado como fotocatalítico si simultáneamente se cumplen las siguientes condiciones (23):

\section{$R_{4}>20 \%$}

$R_{26}>50 \%$

En otra serie de experimentos para determinar las propiedades de auto-limpieza se empleó vino tinto como tinte orgánico sobre materiales a base de cemento del tipo Eternit que fueron recubiertos con $\mathrm{TiO}_{2} / \mathrm{SiO}_{2}$. Después de 48 horas de exposición a luz UV (simulador solar Suntest, $90 \mathrm{~mW} / \mathrm{cm}^{2}$ ) se observó una completa recuperación del color (Figura 5) (24).

Los prometedores resultados obtenidos a escala de laboratorio con el dióxido de titanio aplicado a los materiales a base de cemento para desarrollar actividad auto-limpiante, permitieron a los investigadores continuar a otro
Furthermore, the hydraulic binder is considered as photocatalytic, if the following conditions are simultaneously fulfilled (23):

$R_{4}>20 \%$

$R_{26}>50 \%$

In other series of experiments, using red wine as organic dye, the self-cleaning ability of different cementitious materials coated with $\mathrm{TiO}_{2}$ was determined. After 48 hours of UV irradiation (Suntest solar simulator, $90 \mathrm{~mW} / \mathrm{cm}^{2}$ ) on cement based Eternit plates modified by $\mathrm{TiO}_{2} / \mathrm{SiO}_{2}$ surface layers, a complete colour recovering was observed (Figure 5) (24).

The promising results obtained at laboratory scale with the titanium dioxide applied to cementitious materials with self-cleaning purposes allowed researchers to continue to another stage for developing this type of

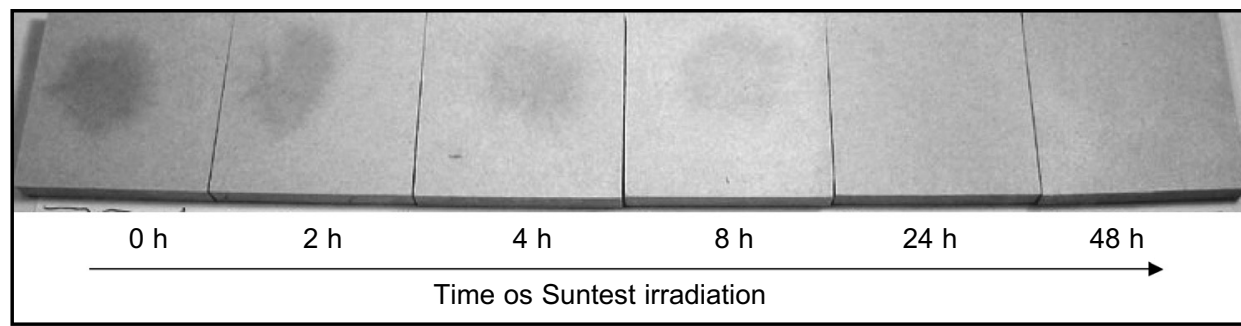

Figura 5. Decoloración de manchas de vino tinto sobre placas de $\mathrm{TiO}_{2} / \mathrm{SiO}_{2} /$ Eternit en función del tiempo de irradiación (24). Figure 5. Red wine stains discoloration on $\mathrm{TiO}_{2} / \mathrm{SiO}_{2} /$ Eternit plates as a function of irradiation time (24). 
nivel en el desarrollo de este tipo de materiales. De este modo, actualmente algunos edificios construidos con materiales a base de cemento que contienen $\mathrm{TiO}_{2}$ ya han sido construidos y están en uso. La iglesia "Dives in Misericordia" (Roma, Italia) y el edificio público "Cité de la Musique et des Beaux-Arts" (Chambery, Francia) son dos de los más referenciados. Sin embargo, también existen ya otras edificaciones de hormigón terminadas en Bélgica, Francia, Italia, Mónaco, Marruecos, Japón y China. En general, la iglesia construida en Roma es una estructura conformada por 346 paneles blancos pre-fabricados mientras que el edificio de Chambery es una estructura fabricada in-situ con cemento gris claro. En ambas estructuras está en proceso, un interesante programa de monitorización continuo del color.

Para obtener superficies auto-limpiantes en estos dos edificios, fueron adicionadas partículas de $\mathrm{TiO}_{2}$ a los cementos de sus mezclas de hormigón. La composición de la mezcla del hormigón de la iglesia romana puede verse en la Tabla 1 . Con base en diferentes ensayos mecánicos desarrollados en esta mezcla especial de hormigón, no se detectó efecto colateral alguno en la resistencia a la compresión, tensión indirecta y flexión. Valores de $86,2 \mathrm{MPa}, 7,0 \mathrm{MPa}$ y $10,4 \mathrm{MPa}$ fueron las resistencias obtenidas a la compresión, tensión indirecta y flexión respectivamente después de los 28 días (20). Sin embargo, habría sido aconsejable una comparación de los anteriores resultados con otros de los mismos ensayos usando muestras de referencia (sin contenido de $\mathrm{TiO}_{2}$ ). En relación a la durabilidad, debido a la presencia de partículas de $\mathrm{TiO}_{2}$ un incremento en la resistencia al congelamiento fue reportado por el Instituto Sueco de Investigación del Cemento y del Hormigón (Swedish Cement and Concrete Research Institute) en el estudio denominado "the use of titanium dioxide on concrete elements: concrete properties and self-cleaning effect". Adicionalmente, una posible interferencia con los aditivos orgánicos en las mezclas de hormigón es mencionado también en la referencia (23).

Durante el programa de monitorización continuo del color en la iglesia romana, las mediciones fueron hechas utilizando un Miniscan XE colorimeter (Hunter lab). El programa está basado en mediciones ejecutadas sobre las superficies de las tres naves, tanto en las superficies materials. Nowadays, some buildings with $\mathrm{TiO}_{2}$ loaded materials have been erected and are in used. The most referenced buildings are the Church the "Dives in Misericordia" (Rome, Italy) and the public building "Cité de la Musique et des Beaux-Arts" (Chambery, France). However, other concrete buildings have been also erected in Belgium, France, Italy, Monaco, Morocco, Japan and China. In general, the church built in Rome is a structure made with 346 precast white concrete panels, while the Chambery's building is a structure cast in situ with light grey cement. In both structures, an interesting continuous colorimetric program is running.

In order to obtain self-cleaning surfaces on these two buildings, $\mathrm{TiO}_{2}$ particles were added to the cement from their concrete mixes. The mix design for the concrete of the roman church can be seen in Table 1. Based on different mechanical tests on this special concrete mix, no negative effect on the compressive, indirect tensile and flexural strengths was detected. After 28 days, compressive, indirect tensile and flexural strengths amounted around 86.2 $\mathrm{MPa}$, 7.0 $\mathrm{MPa}$ and 10.4 MPa, respectively (20). However, a comparison of the previous results with results from the same tests using reference samples (not containing $\mathrm{TiO}_{2}$ ) was advisable. In relation to durability, an increase in the frost resistance due to the presence of titanium dioxide nanoparticles in the concrete mix was reported by the Swedish Cement and Concrete Research Institute in their study named "the use of titanium dioxide on concrete elements: concrete properties and self-cleaning effect". Furthermore, a possible interference with organic admixtures is also mentioned at reference (23).

During the colour monitoring program in the roman church, the measurements were done using a Miniscan $X E$ colorimeter (Hunter lab). The program is based on measurements executed on the surface of the three sails, internal and external surfaces. Thirty panels were

Tabla 1 / Table 1

Composición de la mezcla de hormigón de "Dives in Misericordia" (20).

Mix proportion of white concrete mixture of "Dives in Misericordia" (20).

\begin{tabular}{|c|c|}
\hline Cemento blanco con $\mathrm{TiO}_{2}(5 \%) /$ White cement with $\mathrm{TiO}_{2}(5 \%)$ & $380 \mathrm{~kg} / \mathrm{m}^{3}$ \\
\hline Metacaolín blanco (con agente compatibilizante) / White metakaolin (with compatibilizing agent) & $38.7 \mathrm{~kg} / \mathrm{m}^{3}$ \\
\hline Agregados: mármol triturado $\mathrm{d}_{\text {máx }}=20 \mathrm{~mm} /$ Aggregates: Crushed marble $d_{\max }=20 \mathrm{~mm}$ & $1850 \mathrm{~kg} / \mathrm{m}^{3}$ \\
\hline Superplastificante acrílico (solución 30\% extracto seco) / Acrylic superplasticizer (solution 30\% dry extract) & $10.5 \mathrm{~kg} / \mathrm{m}^{3}$ \\
\hline Agua / Water & $160 \mathrm{l} / \mathrm{m}^{3}$ \\
\hline
\end{tabular}


internas como en las externas. Fueron elegidos treinta paneles y estudiados 5 puntos en cada panel (se realizaron 6 mediciones en cada punto). Todas las mediciones del color estuvieron basadas en el sistema del color CIE L*a*b*. Sin embargo, un mejor análisis de los cambios de color en el tiempo puede realizarse mediante el cálculo con estos valores del parámetro $\Delta \mathrm{E}$, ya que éste estima los cambios de color en la superficie de un material al tiempo t en relación al color de la superficie al tiempo $\mathrm{t}=0$. Su cálculo se realiza tal como se muestra a continuación, ec. [5]: chosen and 5 points in each panel were studied (6 measurements were done in each point). All colour measurements were based on the CIE $L^{*} a * b *$ colour system. However, because $\Delta E$ parameter estimates colour changes on a material surface at the time trelated to the surface colour at time $t=0$, by calculating this, a better analysis of the colour changes in time could be done. Its calculation can be done as follow eq. [5]:

$$
\Delta \mathrm{E}=\left(\Delta \mathrm{L} * 2+\Delta \mathrm{a} * 2+\Delta \mathrm{b}^{* 2}\right)^{1 / 2}
$$

Siendo: $\Delta \mathrm{L}=\mathrm{L}_{\mathrm{t}}{ }^{*}-\mathrm{L}_{0}{ }^{*} ; \Delta \mathrm{a}=\mathrm{at}_{\mathrm{t}}{ }^{*}-\mathrm{a}_{0}{ }^{*} ; \Delta \mathrm{b}=\mathrm{b}_{\mathrm{t}}{ }^{*}-\mathrm{b}_{0}{ }^{*}$

Por otro lado, basados en la simulación de ordenador que estima la percepción humana de los cambios de color después de la rehabilitación estética de las estructuras de hormigón, los cambios de color producidos en los edificios que contienen $\mathrm{TiO}_{2}$ pueden ser evaluados siguiendo los parámetros indicados en la Tabla 2 (25). being $\Delta L=L_{t}{ }^{*}-L_{0}{ }^{*} ; \Delta a=a_{t}{ }^{*}-a_{0}{ }^{*} ; \Delta b=b_{t}{ }^{*}-b_{0}{ }^{*}$

On the other hand, based on the computer simulation that estimates the human perception of the colour changes after the aesthetic rehabilitation of concrete structures, the produced colour changes at the $\mathrm{TiO}_{2}$ containing buildings could be assessed following the parameters indicated at Table 2 (25).

Tabla 2 / Table 2

Percepción humana de los cambios de color con base en los valores de $\Delta \mathrm{E}$ (25). Human perception of the colour changes based on $\Delta E$ values (25).

\begin{tabular}{|c|c|}
\hline Cambio de color $(\Delta \mathrm{E})$ / Colour Change $(\Delta \mathrm{E})$ & Percepción humana / Human perception \\
\hline $0.0-0.2$ & No observable / Not visible \\
\hline $0.2-0.5$ & Muy sutil / Very slight \\
\hline $0.5-1.5$ & Sutil / Slight \\
\hline $1.5-3.0$ & Evidente / Obvious \\
\hline $3.0-6.0$ & Muy evidente / Very obvious \\
\hline $6.0-12.0$ & Grande / Large \\
\hline$>12.0$ & Muy grande / Very large \\
\hline
\end{tabular}

Calculando el $\Delta \mathrm{E}$ de las mediciones colorimétricas de la iglesia "Dives in Misericordia" las cuales fueron publicadas en la referencia (26) (Figura 6), puede concluirse que las tres naves (superficies externas e internas) se comportaron de la misma manera durante el periodo de construcción (tres primeros años). Al finalizar la construcción, sobre las tres naves se presentaron cambios sutiles de color. Sin embargo, quizás, por un lado, debido a la blancura de los paneles pre-fabricados $y$, por otro, debido a la polución del aire generada durante el proceso constructivo, estos sutiles cambios de color eran esperados. Dos años después del periodo de construcción ( $5^{\circ}$ año), la situación no fue la misma, se observaron cambios de color mayores en las superficies externas que en las internas. Durante el último año de los datos constatados (60 año), no se detectó recuperación alguna del color. Sin embargo, se evidenció una tendencia a la estabilización del color.
Calculating the $\Delta E$ from the colorimetric measurements of the Church "Dives in Misericordia" which were published in reference (26) (Figure 6), it can be concluded that the three sails (external and internal surfaces) behaved in the same way during the construction period (first three years). On the three sails slight colour changes were evidenced at the end of the construction period. However, perhaps due to the whiteness of the white pre-cast panels on one hand and to the air pollution generated during the construction process on the other hand, these slight colour changes were expected. Two years after the end of the construction period (5th year), the situation is not the same, bigger colour changes on external surfaces than on internal surfaces were noted. During the last year of the reported data ( $6^{\text {th }}$ year), no recovering of the colour was detected. However, a tendency to stabilize colour changes was evidenced. 


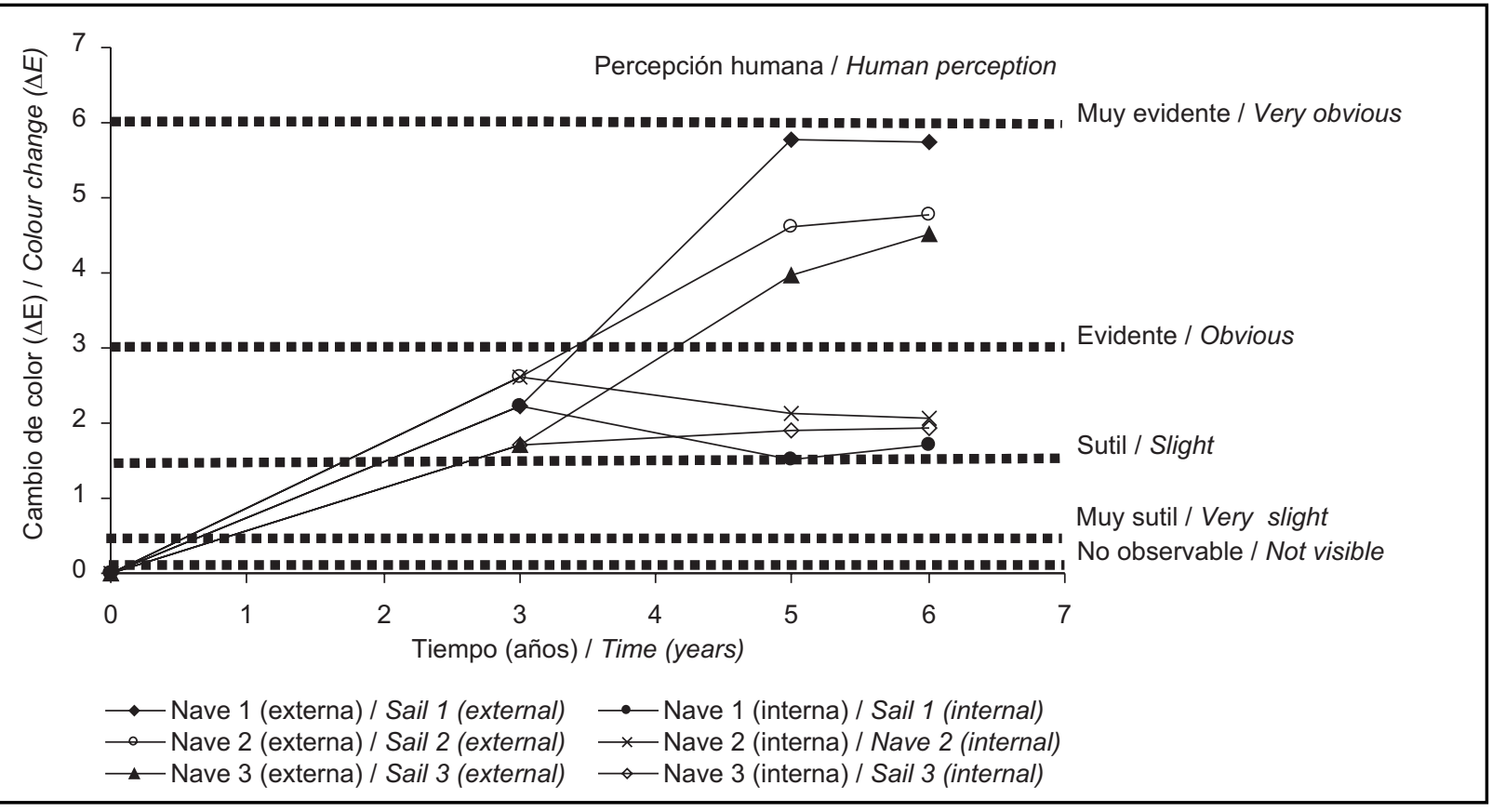

Figura 6. Percepción humana de los cambios de color en 3 naves de la iglesia "Dives in Misericordia (Roma, Italia). Los cálculos están basados en los resultados de la referencia (26).

Figure 6. Human perception of colour changes from 3 different sails of the church "Dives in Misericordia (Rome, Italy). Calculations are based on results from reference (26).

En el caso del complejo público en Chambery (Francia), el programa de monitorización del color ha sido ejecutado utilizando 191 puntos de medición también basados en el sistema de color CIE L*a*b*. Estos puntos fueron distribuidos precisamente a lo largo de los cuatro puntos cardinales y dentro de los dos edificios que los conforman (un edificio principal en la posición norte y un edificio secundario en la posición sur). Las mediciones colorimétricas han sido hechas utilizando un colorímetro marca Minolta CR-410, el cual es un colorímetro portable que considera un área media de referencia de $6,6 \mathrm{~cm}^{2}$. Calculando $\Delta \mathrm{E}$ de los resultados publicados en la referencia (26), los cambios colorimétricos y su percepción humana se resumen en la Figura 7. Nótese que durante el periodo en estudio las fachadas Norte y Este mostraron el mismo comportamiento en relación a los cambios del color, lo cual puede ser debido al mismo grado de exposición a los contaminantes del aire. En el mismo periodo, la fachada Oeste presentó, comparada con las otras fachadas, los más bajos cambios del color, lo cual se deba quizás a que posee una posición especial en relación al viento y/o dirección de la lluvia, que son factores que pueden disminuir el grado de exposición de esta superficie a los contaminantes del aire. La fachada sur tiene un comportamiento diferente a las otras pero con valores similares de cambio de color comparado con las fachadas Norte y Este. En general, sobre todas las fachadas de este edificio, los cambios de color producidos durante 56 meses ( 5 años) fueron pequeños, cambiando tan sólo de muy sutil a sutil, aun más, al final del periodo de estudio, cambios de color de aproximadamente igual magnitud se obtuvieron en todas las fachadas.
In the case of the public complex in Chambery (France), the colour monitoring programme has been carried out using 191 measurement points also based on the CIE lab colour system. These points are accurately distributed among the four cardinal points and between the two buildings which form it (a main building in north position and a secondary building in south position). Colorimetric measurements have been done using a Minolta Chromameter CR-410 which is a portable colorimeter that considers a $6.6 \mathrm{~cm}^{2}$ mean reference area. Calculating $\Delta E$ from the colorimetric measurements published in reference (26), colorimetric changes and their human perception can be summarized in Figure 7. Note that during the studied period north and east facades showed the same behaviour in relation to their colour changes, this could be due to the same degree of exposure to coloured air pollutants. In the same period, the west facade presented the lowest changes in colour compared to the other facades perhaps because it has an especial position in relation to wind and/or rain direction which could decrease the degree exposure of this surface to coloured air pollutants. The south facade has a different behaviour to all facades but similar colour change values compared to facades north and east. In general, on all facades from this building the colour changes produced during 56 months (5 years) were small varying only from very slight to slight, even similar colour change values were obtained for all facades at the end of the studied period. 


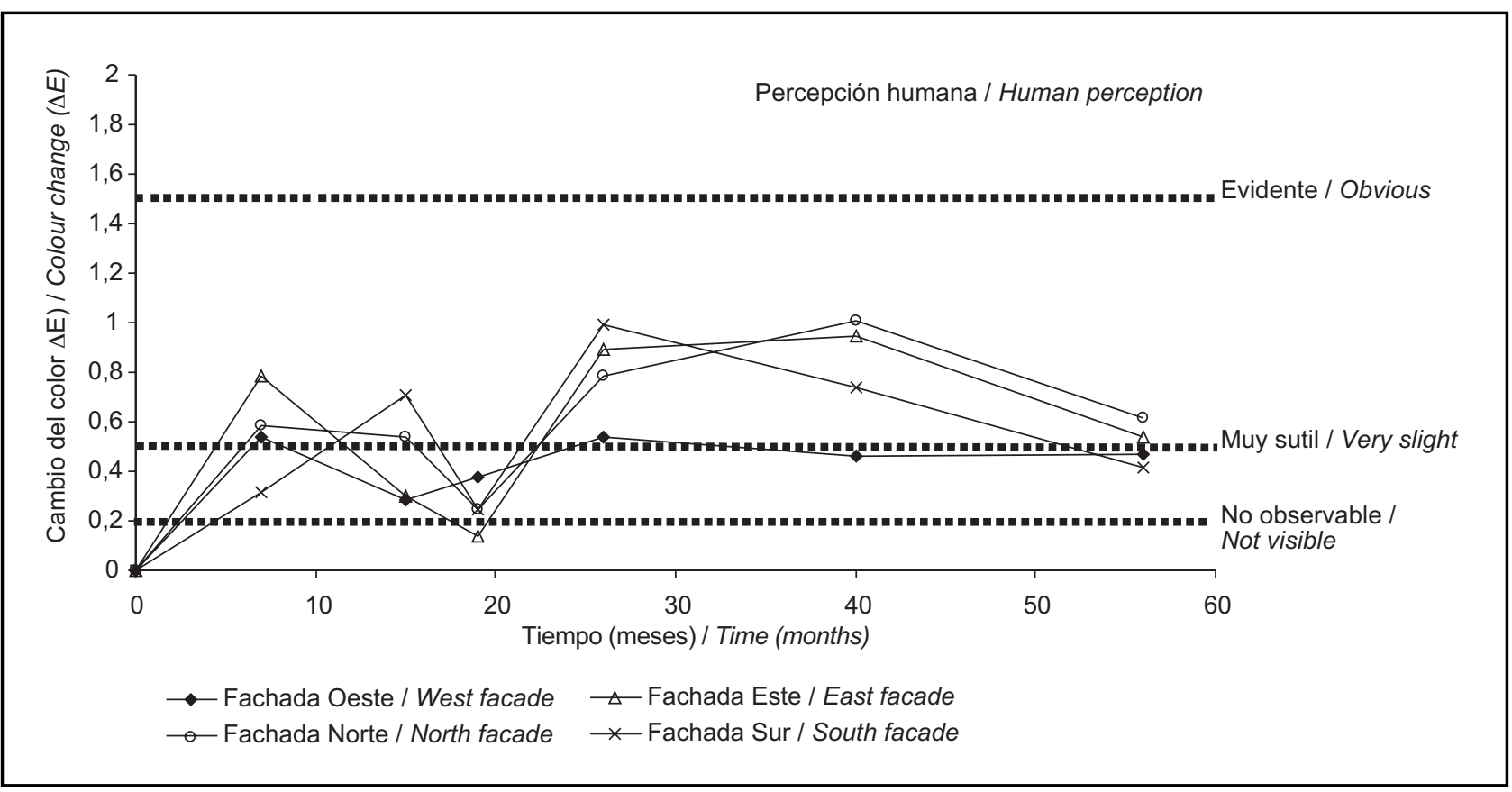

Figura 7. Percepción humana de los cambios de color en 4 fachadas del complejo público ubicado en Chambery (Francia). Los cálculos están basados en los resultados de la referencia (26).

Figure 7. Human perception of color changes at 4 different facades of the public complex in Chambery (France). Calculations are based on results from reference (26).

Si bien no existen comparaciones entre los cambios de color producidos en las superficies de los edificios y algunos paneles de referencia ( $\sin$ contenido de $\mathrm{TiO}_{2}$ ), los resultados tanto de la iglesia "Dives in Misericordia" y del complejo público de Chambery son prometedores, pues fue evidente una tendencia a mantener el color original de los edificios. Sin embargo, para un mejor entendimiento de la acción fotocatalítica del $\mathrm{TiO}_{2}$ en estas aplicaciones, se deberían desarrollar correlaciones entre los cambios de color producidos en las superficies, las condiciones ambientales y los planos arquitectónicos.

En relación al crecimiento microbiano sobre los materiales a base de cemento, además de las condiciones ambientales (alta humedad y disponibilidad de luz solar), el establecimiento, anclaje y desarrollo de diferentes micro-organismos tales como hongos, cyanobacterias y algas es un fenómeno común debido a la alta rugosidad, alta porosidad y rica composición mineral de los materiales a base de cemento. En el caso de las algas, éstas tienen el potencial de causar manchas en la superficie, producir cambios químicos y disminuir la durabilidad de los materiales a base de cemento (27).

El dióxido de titanio ha mostrado habilidad para descomponer los compuestos orgánicos de la parte externa de la membrana celular de algunos micro-organismos causando así la muerte de la célula. Con base a esto, el $\mathrm{TiO}_{2}$ ha sido estudiado para eliminar la bacteria $E$. Coli en el tratamiento de aguas (14). También, usando dióxido de
The results from both the church "Dives in Misericordia" and the public complex of Chambery are promising; a tendency to keep the original colour of the buildings was evidenced. However, for a better understanding of the photocatalytic action of $\mathrm{TiO}_{2}$ on these applications, correlation between the color changes produced on the surfaces, the environmental conditions and the architectural plans should be developed. Furthermore, the comparison between the colour changes produced on the building surfaces and some reference panels could be advisable.

In relation to microbial growth on cementitious materials, besides environmental conditions (high humidity and sunlight availability), due to the high roughness, high porosity and rich mineral composition of cementitious materials, the establishment, anchorage and development of different micro-organisms such as algae, fungi and cyanobacteria is a common phenomenon. The later has the potential to cause surface staining; produce chemical changes and decrease durability of cement based materials (27).

Titanium dioxide has shown ability to decompose organic compounds from the outer cell membrane of some micro-organisms which causes cell death. Based on this, $\mathrm{TiO}_{2}$ has been studied to eliminate the bacteria E.Coli in water treatments (14). Also, using titanium dioxide (Degussa P-25) complete photodegradation of algae 
titanio (Degussa P-25) se ha logrado la completa fotodegradación de alga (Cladophora). Experimentos in-vitro mostraron que las muestras de cladophora fueron física y biológicamente degradadas cuando se sometieron a la fotocatálisis generada por el $\mathrm{TiO}_{2}$. Se obtuvieron los mejores resultados fotocatalíticos cuando el dióxido de titanio fue inmovilizado sobre una superficie de vidrio y utilizado en combinación con luz solar o luz UV artificial. La pérdida de los pigmentos vitales fue monitorizada usando UV-vis espectrofotometría, y los cambios en la estructura de la célula fueron determinados a través de observación microscópica. La cladophora en presencia de los soportes de vidrio recubierto con $\mathrm{TiO}_{2}$ experimentó una pérdida de los pigmentos cloroplasmáticos después de 2 horas de irradiación con luz UV (450 W Hg lámpara de vapor). En un experimento paralelo, la exposición a la luz solar durante 4 días ( 24 horas) del mismo tipo de muestras, resultó con la degradación completa de los pigmentos verdes cloroplasmáticos, lo cual fue verificado por el análisis del espectro UV de los extractos de algas (4). Estos resultados sugieren que el dióxido de titanio inmobilizado sobre la superficie de materiales a base de cemento puede ser útil en el control del crecimiento del alga, logrando así mitigar muchos de los impactos estéticos, económicos y ecológicos del crecimiento de alga en los materiales a base de cemento.

Utilizando un equipo recientemente desarrollado para el crecimiento acelerado de algas sobre materiales a base de cemento, un ensayo preliminar para evaluar el efecto alguicida de un recubrimiento de $\mathrm{TiO}_{2}$ aplicado a muestras de hormigón blanco aireado fueron desarrrollados durante 5 semanas en el Laboratorio Magnel para la Investigación del Hormigón (Magnel Laboratory for Concrete Research, Ghent University, Bélgica). El equipo consta de doce módulos independientes para diferentes tipos de muestras. Un módulo independiente está compuesto de una superficie inclinada de acero inoxidable para colocar las muestras, un reactor aereado para el crecimiento del alga y un sistema de bombeo para dispersar periódicamente la suspensión de algas sobre las muestras durante 90 minutos. Periodos correspondientes al día y la noche fueron simulados cada 12 horas. Los periodos de día fueron reproducidos con lámparas Grolux (30W). La iluminación alcanzó valores desde $800 \pm 84$ lux en la parte superior, $524 \pm 62$ en la parte media y $448 \pm 114$ lux en la parte baja de los módulos. Después de cada semana de ensayo, la evaluación del crecimiento del alga se realizó por medio del análisis de imágenes y mediciones del color. Las mediciones del color fueron desarrolladas usando un colorímetro marca X-Rite SP60. Tres mediciones fueron tomadas en posiciones estándares sobre las muestras. Para el análisis de imágenes, se obtuvieron fotografías de las muestras con el uso de un escáner marca Canon Scan 3000F. Posteriormente, las imágenes fueron procesadas por medio del software ImageJ 1.38x (28).
(Cladophora) has been reported. In vitro experiments showed that Cladophora samples were physical and biologically degraded when subjected to $\mathrm{TiO}_{2}$ mediated photocatalysis. For the most successful photocatalytic process, $\mathrm{TiO}_{2}$ was immobilized on a glass surface and used in combination with either sunlight or artificial UV light. The loss of vital algae pigments was monitored using UV-vis spectrophotometry, and cell structural changes were determined by microscopy observation. Cladophora, in presence of $\mathrm{TiO}_{2}$ covered glass beads, experienced a loss of chloroplast pigments after $2 \mathrm{~h}$ of UV lamp light irradiation (450 W $\mathrm{Hg}$ vapour lamp). In a separate experiment, sunlight exposure of the same sample type over 4 days $(\sim 24 h)$ resulted in the complete oxidative degradation of the green chloroplast pigments, verified by the UV spectra of the algal extracts (4). These results suggest that $\mathrm{TiO}_{2}$ immobilized on cementitious materials may be useful in controlling algae growth which minimizes many of the economic, aesthetic and ecological impacts of algae growth on cementitious materials.

Using a recently developed equipment for accelerated algae growth on cementitious materials, preliminary tests for evaluating algicidal effect of $\mathrm{TiO}_{2}$ coatings applied on autoclaved aerated concrete samples were performed during 5 weeks in the Magnel Laboratory for Concrete Research (Ghent University, Belgium). The equipment consists of twelve independent compartments for different sample types. One single compartment is composed of inclined stainless steel surfaces to place the samples, an aerated reactor for growing an algae suspension and a pumping system to periodically scatter the algae suspension on the samples surfaces during 90 minutes. Day and night periods were reproduced every 12 hours. Day periods were simulated with Grolux lamps (30W). The illumination amounted to $800 \pm 84$ lux, $524 \pm 62$ and $448 \pm 114$ lux at the upper and lower part of the stainless steel compartment. After each test week, evaluation of the algae growth was done by image analyses and colorimetric measurements. Colorimetric measurements were performed by using an X-Rite SP60 colorimeter. Three measurements were taken at standard positions on the samples. For the image analysis, photographs of the samples were obtained with the use of a Canon Scan 3000F scanner. Afterwards, the images were processed by means of Image J 1.38x software (28). 
Como el crecimiento de algas es un proceso biológico, dos semanas previas fueron necesarias para obtener condiciones óptimas de crecimiento en el ensayo, por lo tanto, los resultados de este periodo no son representativos y, consecuentemente, no se presentan aquí. Los resultados del análisis de las imágenes pueden observarse en la Figura 8. En relación a unas muestras de referencia ( $\sin$ recubrimiento de $\mathrm{TiO}_{2}$ ), las muestras recubiertas con $\mathrm{TiO}_{2}$ evidenciaron una foto-degradación parcial del alga Chlorella vulgaris. Durante las dos primeras semanas las muestras de referencia y las muestras recubiertas con $\mathrm{TiO}_{2}$ se comportaron similarmente, mostrando un insignificante crecimiento de alga sobre las superficies. Sin embargo, después de la tercera semana un incremento significativo en el crecimiento del alga fue observado en ambos tipos de muestras; especialmente en las muestras de referencia las cuales mostraron un área cubierta con alga igual al 75\% mientras que aproximadamente esta misma variable alcanzó un valor de sólo el $25 \%$ en las muestras recubiertas con $\mathrm{TiO}_{2}$. Después de la cuarta semana, nuevamente se presentó un incremento del área cubierta con alga en ambos tipos de muestras; especialmente en la muestras de referencia, las cuales se encontraban recubiertas con alga en un $100 \%$ mientras las muestras que poseían $\mathrm{TiO}_{2}$ mostraban un área recubierta de sólo el $60 \%$. Después de todo el ensayo (cinco semanas), las muestras recubiertas con $\mathrm{TiO}_{2}$ presentaron un área cubierta con alga constante alrededor del $60 \%$. Este valor es prometedor dadas las condiciones aceleradas para el crecimiento de alga en este ensayo y también porque la fotodegradación de la misma fue obtenida con luz UV proveniente de luz fluorescente $(30 \mathrm{~W})$, la cual fue incluso periódicamente apagada. Adicionalmente, algunos problemas de resistencia al desgaste sobre las superficies recubiertas con $\mathrm{TiO}_{2}$ se
As algae growth is a biological process, two previous weeks were needed to obtain optimal growing conditions of the algae in the set-up, so results from this period are not representative and as a consequence not presented here. Results from images analysis can be seen in Figure 8. In relation to some reference samples (non $\mathrm{TiO}_{2}$ coated samples), $\mathrm{TiO}_{2}$ coated samples evidenced partial photodegradation of Chlorella vulgaris. During the first two weeks, the reference samples and the $\mathrm{TiO}_{2}$ coated samples behaved similarly, showing no significant growth of algae on their surfaces. However after the third week, a significant increase in the algae growth was observed in both cases, especially on the reference samples which showed an area covered with algae equal to $75 \%$ while approximately this variable was only $25 \%$ on the $\mathrm{TiO}_{2}$ coated samples. After the fourth week, again, an increase of the area covered with algae was noted on both sample types, especially on references samples which were covered almost $100 \%$ while $\mathrm{TiO}_{2}$ coated samples were covered only $60 \%$. After the whole test (five weeks), $\mathrm{TiO}_{2}$ coated samples presented a constant covered area with algae of around $60 \%$. This value is promising because of the accelerated conditions for the algae growth during the test, and also because the algae photodegradation was obtained with UV light coming from fluorescent light (30W) which was even periodically switched off. Furthermore, weathering resistance problems on the $\mathrm{TiO}_{2}$ coatings were evidenced during the test, so that

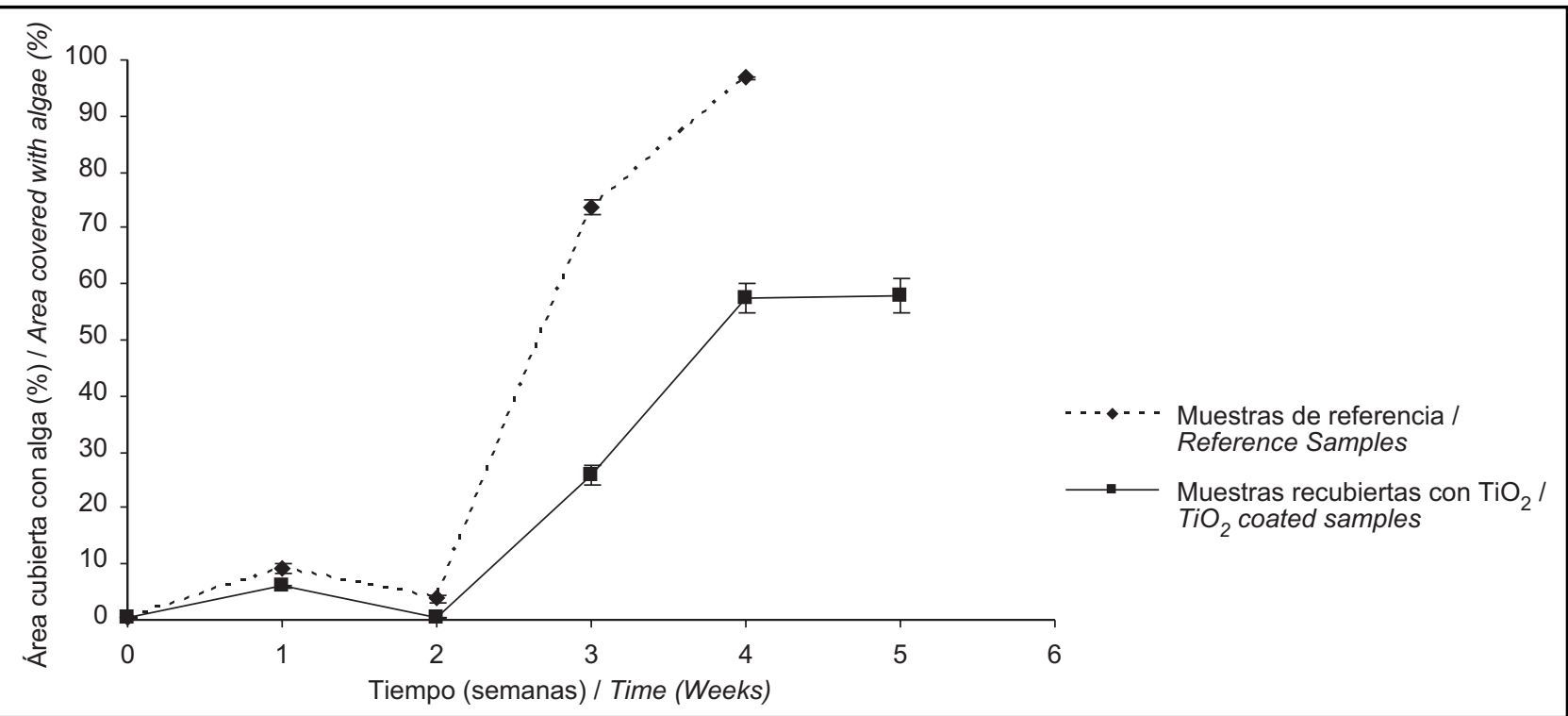

Figura 8. Área cubierta con alga sobre muestras de hormigón aireado después del ensayo de crecimiento acelerado de alga (5 semanas) (29). Figure 8. Area covered with algae on autoclaved aerated concrete samples after accelerated algae growth test (5 weeks) (29). 
pusieron de manifiesto durante el ensayo, por lo que las muestras recubiertas con $\mathrm{TiO}_{2}$ no mostraron su capacidad real alguicida durante todo el ensayo (29).

\section{CONCLUSIONES}

Se ha demostrado a través de los ensayos de laboratorio y los proyectos pilotos que la fotocatálisis del dióxido de titanio ha mejorado la durabilidad de las propiedades estéticas de los materiales a base de cemento; específicamente incrementando el potencial de mantener los colores originales. La degradación fotocatalítica de colorantes orgánicos rojos y amarillos usando $\mathrm{TiO}_{2}$, permite pensar que este proceso de limpieza -respetuoso con el medio ambiente-, es capaz de degradar los contaminantes orgánicos colorantes que manchan los materiales a base de cemento.

Sin embargo, aún existe un vacío de conocimiento sobre el proceso de fotodegradación de los contaminantes orgánicos en los materiales a base de cemento. Un mejor conocimiento de las variables que controlan la fotocatalísis sobre los materiales a base de cemento podría permitir hacer más eficiente esta nueva tecnología. Por ejemplo, variables ambientales tales como la temperatura del aire, la humedad relativa, la intensidad de la luz solar y la concentración de los contaminantes orgánicos capaces de manchar los materiales deberían ser estudiados en relación a aspectos tales como el tamaño de las partículas de $\mathrm{TiO}_{2}$, el tamaño del cristal de $\mathrm{TiO}_{2}$, el tipo de cristal, la distribución de las partículas de $\mathrm{TiO}_{2}$ en la superficie, y las propiedades de la matriz de cemento (porosidad, humectabilidad, etc.).

En general, la simplicidad y el corto tiempo empleado en los ensayos de laboratorio para evaluar las propiedades de auto-limpieza fue destacable. Por esta razón, se puede afirmar que los ensayos de degradación de colorantes orgánicos pueden ser utilizados para evaluar rápidamente la fotoactividad de los diferentes productos de $\mathrm{TiO}_{2}$ en los materiales a base de cemento. Sin embargo, se identificó la necesidad de estandarizar el tipo de fuente de rayos UV, el colorante, las muestras, el procedimiento, etc. No obstante, se encontró que la rodamina B fue el colorante más empleado dentro de los diferentes ensayos, quizás porque éste tiene una anthrancene moiety y, como tal, está relacionada con una cadena policíclica de hidrocarburos aromáticos (PHA, polycyclic aromatic hydrocarbon) los cuales están dentro de los agentes contaminantes más comunes en los ambientes urbanos (21). También fueron utilizados diferentes tipos de fuente de rayos UV en todos los experimentos de laboratorio. Sin embargo, como era de esperar, con lámparas UV la fotodegradación de los colorantes fue más rápida que con otras lámparas. En general, se encontró una tendencia a the $\mathrm{TiO}_{2}$ coated samples did not show their full algicidal capacity during the complete test (29).

\section{CONCLUSIONS}

Titanium dioxide photocatalysis has improved the durability of the aesthetical properties of cementitious materials; specifically, it has increased the potential to keep their original colors. Laboratory tests and the first pilot projects have confirmed this useful property. $\mathrm{TiO}_{2}$ photodegradation of red and yellow organic dyes allows thinking that this environmentally friendly cleaning process is able to degrade colored organic pollutants that stain the surface of the cement based materials.

Nevertheless, a lack of knowledge about the processes itself of photo-degradation of the organic pollutants on cement based materials was found. A better understanding of the variables controlling the photocatalysis on cementitious materials could allow us to make more efficient this novel technology. For example, environmental variables such as temperature, relative humidity, sun light intensity, and colored organic pollutant concentrations in the air should be studied in relation to aspects such as $\mathrm{TiO}_{2}$ particle size, $\mathrm{TiO}_{2}$ crystal type, $\mathrm{TiO}_{2}$ particles distribution on the substrate surface, properties of the cementitious matrix (porosity, wetability, etc.).

In general, the simplicity and short time expended on the laboratory tests for evaluating the self-cleaning ability of $\mathrm{TiO}_{2}$ loaded cementitious materials was remarkable. For this reason, it could be said that tests of degradation of organic dyes could be used to quickly evaluate the photoactivity of the different $\mathrm{TiO}_{2}$ products on cementitious materials. However, a need for standardization of the UV light source, dye, samples, procedure, etc., was identified. In this sense, rhodamine $B$ was the most used dye among the tests, perhaps because this has an antracene moiety and as such is related to a PAH (polycyclic aromatic hydrocarbon) which are among the most common soiling agents found in urban environments (21). Also, different UV sources were used in all the laboratory experiments. Nevertheless, as was expected with UV lamps the photo-degradation of the different dyes was higher than with other lamps. In general, a tendency to use the CIE $L^{*} a^{*} b^{*}$ color system as color indicator was also found. The use of parameters like $\Delta E, R_{4}, R_{26}, V_{L *}$, $V_{a *}$ and $V_{b *}$ allows to compare the behavior of the 
utilizar el sistema de color CIE L*a*b* como indicador de los cambios del color. El uso de parámetros como $\Delta \mathrm{E}_{1} \mathrm{R}_{4}$, $\mathrm{R}_{26}, \mathrm{~V}_{\mathrm{L}}, \mathrm{V}_{\mathrm{a}}$ y $\mathrm{V}_{\mathrm{b}}$ * permiten comparar el comportamiento de los diferentes productos de $\mathrm{TiO}_{2}$ sobre los materiales a base de cemento; sin embargo deberían desarrollarse algunas correlaciones entre ellas.

No obstante, aun cuando los primeros edificios que contienen $\mathrm{TiO}_{2}$, la iglesia "Dives in Misericordia" y el edificio público en Chambery, evidenciaron una buena actividad fotocatalítica para la degradación de contaminantes colorantes orgánicos del aire, deberían hacerse mayores esfuerzos para reducir la cantidad de $\mathrm{TiO}_{2}$ utilizado considerando los precios del $\mathrm{TiO}_{2}$ y lograr, de este modo, hacer más popular esta tecnología. También para aplicaciones del $\mathrm{TiO}_{2}$ como un aditivo en las mezclas, se deben hacer más estudios en relación al aparente incremento en la resistencia al congelamiento y el efecto negativo sobre los aditivos orgánicos.

Considerando la magnitud del crecimiento biológico sobre las superficies de los materiales a base de cemento y el conocido efecto bactericida y alguicida del $\mathrm{TiO}_{2}$ sobre otros materiales, fue sorprendente que no hayan sido encontrados estudios previos sobre estas propiedades en materiales que contienen $\mathrm{TiO}_{2}$. Estudios recientes desarrollados en el Laboratorio Magnel para la Investigación del Hormigón (Magnel Laboratory for Concrete Research, Ghent University, Belgium) acerca del uso de recubrimientos de $\mathrm{TiO}_{2}$ (anastase) como alguicida sobre hormigón aireado son prometedores.

La aplicación de la fotocatalisis generada con el $\mathrm{TiO}_{2}$ en los materiales a base de cemento para desarrollar materiales con propiedades auto-limpiantes es un tema que deja aún muchas preguntas sin responder, razón suficiente para continuar investigando diferentes aspectos de esta nueva tecnología, la cual, en pocos años, parece convertirse en un tema de interés popular debido al impacto que las propiedades de auto-limpieza y purificación del aire del $\mathrm{TiO}_{2}$ tienen sobre la calidad de vida de las ciudades del futuro. different $\mathrm{TiO}_{2}$ products on cementitious materials, however some correlations should be developed.

Even when the church "Dives in misericordia" and the public building in Chambery, the pioneering buildings containing $\mathrm{TiO}_{2}$, evidenced a good photocatalytic activity for degrading colored pollutants from air, considering the $\mathrm{TiO}_{2}$ prices, for making this technology popular, major effort to reduce the used $\mathrm{TiO}_{2}$ amounts should be done. Also, for applications of $\mathrm{TiO}_{2}$ as an additive in the mixes, more studies should be done in relation to the apparent increase in the frost resistance and the negative effect on organic additives of $\mathrm{TiO}_{2}$ additions.

Considering the magnitude of the biological growth on external cementitious materials and the known bactericidal and algicidal effect of $\mathrm{TiO}_{2}$ on other materials, it was surprising that studies about these properties on $\mathrm{TiO}_{2}$ loaded cementitious materials were not found. Recent studies developed at Magnel Laboratory for Concrete Research (Ghent University) about the use of titanium dioxide coatings (anatase) as algaecide coating on autoclaved aerated concretes are promising.

The application of $\mathrm{TiO}_{2}$ photocatalysis on cementitious materials for self-cleaning purposes is a topic which still leaves many questions unanswered, reason to continue researching different aspects of this novel technology which in few years seems to become a topic of popular interest due to the impact of the self-cleaning and airpurifying properties of $\mathrm{TiO}_{2}$ on the life quality of the future cities.

\section{BIBLIOGRAFÍA / BIBLIOGRAPHY}

(1) Marinoni, N.; Pellizon Birelli, M.; Rostagno, Ch.; Pavese, A.: "The effects of atmospheric multipollutants on modern concrete". Atmospheric Environment, vol. 37 (2003), pp. 4701-4712. doi:10.1016/j.atmosenv.2003.06.001

(2) Gaylarde, Ch.; Gaylarde, P.: "A comparative study of the major microbial biomass of biofilms on exteriors of buildings in europe and latin America". Biodeterioration \& Biodegradation, vol. 55 (2005), pp. 31-139.

(3) Kikuchi, Y.; Sunada, K.; Iyoda, T.; Hashimoto, K.; Fujishima, A.: "Photocatalytic bactericidal effect of $\mathrm{TiO}_{2}$ thin films: dynamic view of the active oxygen species responsible for the effect". Photochemistry and Photobiology A: Chemistry, vol. 106, (1997), pp. 51-56.

(4) Peller, J. R.; Whitman, R. L.; Griffith, S.; Harris, P.; Peller, C.; Scalzitti, J.: "TiO 2 as a photocatalyst for control of the aquatic invasive alga, Cladophora, under natural and artificial light". Photochemistry and Photobiology A: Chemistry, vol. 186 (2007), pp. $212-217$.

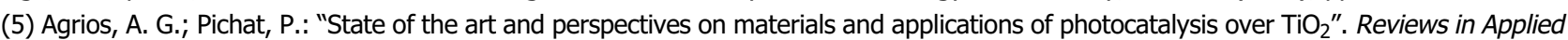
Electrochemistry, vol. 58 (2005), pp. 655-663. doi:10.1007/s10800-005-1627-6

(6) Demeestere, K.; Dewulf, J.; Van Langenhove, H.: "Heterogeneous photocatalysis as an adavanced oxidation process for the abatement of chlorinated, monocyclic aromatic and sulfurous volatile organic compounds in air: state of the art". Critical reviews in Environmental Science and Technology, vol. 37 (2007), pp. 489-538. doi:10.1080/10643380600966467 
(7) Toma, F. L.; Bertrand, G.; Klein, D.; Coddet, C.: "Photocatalytic removal of nitrogen oxides via titanium dioxide". Environ. Chemical Letter 2 (2004), pp. 117-121. doi:10.1007/s10311-004-0087-2

(8) Lin, H.; Huang, C. P.; Li, W.; Ni, C.; Ismat Shah, S.; Yao-Hsuan, Tseng.: "Size dependency of nanocrystalline $\mathrm{TiO}_{2}$ on its optical property and photocatalytic reactivity exemplified by 2-chlorophenol". Applied Catalysis B: Environmental, vol. 68 (2006), pp. 1-11. doi:10.1016/j.apcatb.2006.07.018

(9) Bakardjieva, S.; Stengl, V.; Szatmary, L.; Subrt, J.; Lukac, J.; Murafa, N.; Niznansky, D.; Cizek, K.; Jirkovsky, J.; Petrova, N.: "Transformation of brookite-type $\mathrm{TiO}_{2}$ nanocrystals to rutile: correlation between microstructure and photoactivity". Mater. Chem., vol. 16 (2006), pp. 1709-1716. doi:10.1039/b514632a

(10) Blöß, S. P.; Elfenthal, L.: Doped titanium dioxide as photocatalyst for UV and visible light. Proc. Int. RILEM Symposium on Photocatalysis, Environment and Construction Materials. Florence, Italy. 8-9 October (2007), pp. 31-38.

(11) Fujishima, A.; Honda, K.: "Electrochemical photolysis of water at a semiconductor electrode". Nature, vol. 238 (1972), pp. 7-38. doi:10.1038/238037a0 PMid:12635268

(12) Herrmann, J. M.; Duchamp, C.; Karkmaz, M.; Thu Hoai, Bui; Lachheb, H.; Puzenat, E.; Guillard C.: "Environmental green chemistry as defined by photocatalysis". Hazardous Materials, vol. 146 (2007), pp. 624-629. doi:10.1016/j.jhazmat.2007.04.095 PMid:17532130

(13) Gelover, S.; Gómez, L. A.; Reyes, K.; Leal, M. T.: "A practical demonstration of water disinfection using $\mathrm{TiO}_{2}$ films and sunlight". Water Research, vol. 40 (2006), pp. 3274-3280. doi:10.1016/j.watres.2006.07.006 PMid:16949121

(14) Sunada, K.; Watanabe, T.; Hashimoto, K.: "Studies on photokilling bacteria on $\mathrm{TiO}_{2}$ thin film". Photochemistry and Photobiology A: Chemistry, vol. 156 (2003), pp. 227-233.

(15) Benedix, R.; Dehn, F.; Quaas, J.; Orgass, M.: Application of titanium dioxide photocatalysis to create self-cleaning building materials. Lacer, vol. 5 (2000), pp. 157-168.

(16) Watanabe, T.; Nakajima, A.; Wang, R.; Minabe, M.; Koizumi, S.; Fujishima, A.; Hashimoto, K.: "Photocatalytic activity and photoinduced hydrophilicity of titanium dioxide coated glass". Thin Solid films, vol. 351 (1999), pp. 260-263. doi:10.1016/S0040-6090(99)00205-9

(17) Fujishima, A.; Rao, T. N.; Tryk, D. A.: "Titanium dioxide photocatalysis". Photochemistry and Photobiology C: Photochemistry, Rewievs 1 (2000), pp. 1-21.

(18) Shimohigoshi, M.; Saeki, Y.: "Development of photocatalyst tile and commercial production". Proc. of the RILEM Int. Symposium on Environment-Conscious Materials and Systems for Sustainable Development. Koriyama, Japan. 6-7 September (2004), (handouts), pp. 1-6. (19) Hashimoto, $\mathrm{K}$ : " $\mathrm{TiO}_{2}$ Photocatalysis towards novel building materials". Proceedings International RILEM Symposium on Photocatalysis, Environment and Construction Materials. Florence, Italy. October (2007), pp. 3-8.

(20) Cassar, L.; Pepe, C.; Tognon, G.; Guerrini, G. L.; Amadelli, R.: "White cement for architectural concrete, possessing photocatalytic properties". Proc. of the 11th Int. Congress on the Chemistry of Cement. Durban, South Africa (2003), vol. 4, pp. 1-11.

(21) Vallé, F.; Rout, B.; Guillot, L.; Pimpinelli, N.; Cassar, L.; Strini, A.; Mapelli, E.; Schiavi, L.; Gobin, C.; André, H.; Moussiopoulos, N.; Papadopoulos, A.; Bartzis, J., Maggos, T.; McIntyre, R.; Lehaut-Burnouf, C.; Henrichsen, A.; Laugesen, P.; Amadelli, R.; Kotzias, D.; Pichat P.: "Innovative self-cleaning and de-polluting facade surface". Proc. CIB World Building, Toronto, Canada. 2-7 May, (2004), pp. 1-9.

(22) Dienemann, W.: "Selbstreiningende Fassadenplatten aus Beton: Self-cleaning concrete cladding panels". BFT Betonwerk + FertigteilTechnik. Concrete Plant + Precast technology, vol. 02 (2006), pp. 14-16.

(23) Cassar, L.; Beeldens, A.; Pimpinelli, N.; Guerrini, G. L.: "Photocatalysis of cementitious materials". Proc. Int. RILEM Symposium on Photocatalysis, Environment and Construction Materials. Florence, Italy. 8-9 October (2007), pp. 131-145.

(24) Yuranova, T.; Sarria, V.; Jardim, W.; Rengifo, J.; Pulgarin, C.; Trabesinger, G.; Kiwi, J.: "Photocatalytic discoloration of organic compounds on outdoor building cement panels modified by photoactive coatings". Photochemistry and Photobiology A: Chemestry, vol. 188 (2007), pp. 334-341.

(25) Zhang, Y.; Kruger, D.: "Methodology for aesthetic repair and rehabilitation of architectural concrete". Master Thesis of Engineering and Environment Faculty, University of Johannesburg. Johannesburg, South Africa, February (2005), pp.1-182. Available from: http://etd.rau.ac.za/theses/available/etd-03232006-103034.

(26) Guerrini, G. L., Plassais, A.; Pepe, C.; Cassar, L.: "Use of photocatalytic cementitious materials for self-cleaning applications". Proc. Int. RILEM Symposium on Photocatalysis, Environment and Construction Materials. Florence, Italy. 8-9 October (2007), pp. 219-226.

(27) Kurth, J. C.; Giannantonio, D. J.; Allain, F.; Sobecky, P.; Kurtis, K. E.: "Mitigating biofilm growth through the modification on concrete design and practice". Proc. Int. RILEM Symposium on Photocatalysis, Environment and Construction Materials. Florence, Italy. 8-9 October (2007), pp. 195-202.

(28) De Muynck, W.; Maury Ramirez, A.; De Belie, N.; Verstraete, W.: "Evaluation of strategies to prevent algal fouling on white architectural and cellular concrete". International Biodeterioration \& Biodegradation, vol. 63 (2009), pp. 679-689.

(29) Maury Ramírez, A.; De Belie, N.: "Evaluation of the algaecide activity of titanium dioxide on autoclaved aerated concrete". Journal of Advanced Oxidation Technologies, vol. 12 (2009), pp. 100-104. 